ROCZNIKI TEOLOGICZNE

Tom LXVIII, zeszyt $2-2021$

DOI: https://doi.org/10.18290/rt21682-8

\title{
ECCLESIA SEMPER CONVERTENDA COMO PRINCÍPIO ECLESIOLÓGICO SEGUNDO A EXORTAÇÃO ECCLESIA IN AMERICA DE JOÃO PAULO II ${ }^{*}$
}

\author{
ECCLESIA SEMPER CONVERTENDA AS AN ECCLESIOLOGICAL PRINCIPLE \\ ACCORDING TO THE EXHORTATION OF JOHN PAUL II ECCLESIA IN AMERICA
}

\begin{abstract}
The objective of this article is to verify the hypothesis if Ecclesia semper convertenda is a ecclesiological principle. The study is based on the John Paul II's post-synodal exhortation Ecclesia in America. The hypothesis was verified positively as an ecclesiological principle. Ecclesia semper convertenda embrace: a) the mystery of God as a source of conversion; b) the Revelation in Jesus Christ who reveals to human beings the divine plan of the God's Kingdom through the call to conversion and faith in the Gospel; c) communion with God and with people in the Church as fulfillment of the conversion; d) the accomplishment of the Church's mission as a result of personal and community conversion. Conversion/metanoia has a deeply theological foundation; it comes from Sacred Scripture and addresses the whole life of those who accept the call of Jesus Christ and fully respond. This theme has wide scope and applications and is related to the Christian faith, being hermeneutic of Gospel and the Church.
\end{abstract}

Keywords: conversion; metanoia; Church; John Paul II; Ecclesia in America.

STM EdSOn JosÉ HABle M.I.C. - concluiu o curso de magistério unificado de teologia (Universidade Católica de Lublin João Paulo II). Atualmente estuda na mesma universidade no curso de Licenciatura em Teologia Dogmática. Endereço: ul. Bazylianówka 54B, 20-144 Lublin, Polen; e-mail: hablemic@gmail.com

* Artigo elaborado a partir do trabalho de conclusão de curso de Magistratura em Teologia, redigido pelo mesmo autor na seção de Teologia Dogmática no seminário de Pneumatologia, Eclesiologia, Mariologia sob a direção do padre dr. hab. Kazimierz Pek, professor KUL (Universidade Católica de Lublin João Paulo II): Edson J. Hable, "Ecclesia semper convertenda" jako zasada eklezjologiczna wedtug adhortacji Jana Pawta II "Ecclesia in America", Monografia (Magistratura em Teologia Dogmática), Departamento de Teologia, Universidade Católica de Lublin João Paulo II, Lublin 2020. 


\section{INTRODUÇÃO}

A conversão é uma questão essencial no Evangelho de Jesus Cristo. "Completou-se o tempo e está próximo o Reino de Deus. Convertei-vos e crede no Evangelho" (Mc 1,15). Essa primeira exortação interfere diretamente em toda a mensagem da Boa Nova e na recepção da mesma diante da realidade do reinado de Deus. Acolher a palavra de Deus inclui a cooperação do ser humano em receber a graça presente nela e traduzi-la na vida. A Igreja, como continuadora da missão de Jesus de levar o povo até Deus com a força do Espírito Santo, proclama o oráculo do Senhor e auxilia as pessoas nesta ininterrupta caminhada da realização da vontade do Pai. Como povo de Deus, também vive internamente a dinâmica do Evangelho por ter a missão de ser testemunha fiel do conteúdo do mesmo.

O ser humano é destinatário da Boa Nova de Cristo que, por sua vez, a experiencia por meio da transmissão da Igreja. A mensagem de Cristo engloba a pessoa por inteiro. E, a exemplo dos primeiros discípulos, cada seguidor do Senhor precisa primeiro se encontrar com Ele para, conhecendo-O, poder segui-lo. Aquilo que não está de acordo com a verdade confessada é passível de conversão. Algo análogo acontece com a testemunha do Evangelho que é a Igreja, a qual, como comunidade dos fiéis, anuncia Jesus Cristo e ao mesmo tempo é testemunha Dele; é "lugar" de encontro com o Messias e tem como missão viver como Ele, pois tornar-se-á plenamente realidade do Reino de Deus no fim dos Tempos (cf. Mt 24,36-25.46) ${ }^{1}$. Esse tempo de espera é propício para a humanidade e a Igreja responderem por meio da conversão e da fé no Evangelho. Essa conversão, que deve ser permanente, se expressa pela estável vigilância e busca do cumprimento da vontade de Deus e é forma condizente de acolher a Revelação e tudo aquilo que dela provém. O Magistério da Igreja, em especial o Concílio Vaticano II $^{2}$, desenvolve sobre essa compreensão da Igreja e da vida humana.

A Igreja anuncia a pessoa de Jesus Cristo ${ }^{3}$. Fundada pelo próprio Cristo santa, ruma à santidade dos seus membros. Peregrinos ao Pai, os membros da Igreja são chamados a traduzir o Evangelho com a própria vida, anunciando-o

\footnotetext{
${ }^{1}$ Catecismo da Igreja Católica, Edição Típica Vaticana (São Paulo: Loyola, 2000) [a seguir, Catecismo], 769. Cf. Lumen gentium, 48.

${ }^{2}$ Nos documentos do Concílio a palavra conversão e afins aparece 20 vezes: Sacrosanctum Concilium, 9, 69; Lumen gentium, 11, 46; Unitatis redintegratio, 8; Ad gentes divinitus, 7, 13, 15, 16, 30, 40; Presbyterorum ordinis, 4, 5, 18.

${ }^{3}$ Cf. Paulo VI, Evangelii nuntiandi, 15.
} 
assim aos outros. Caminhantes, ainda não desfrutam da perfeição que é obra da graça, mas sabem que a conversão e a fé os conduzem a este estado de semelhança com Deus (cf. Mt 5,48) e por isso vivem em estado de conversão permanente ${ }^{4}$. O último concílio ecumênico emprega palavras semelhantes (renovação, reforma, edificação, purificação) ${ }^{5}$ para traçar a missão da Igreja no hoje da história.

O Catecismo da Igreja Católica cita a "conversão do coração" como uma das exigências para a unidade da Igreja, para uma maior fidelidade ao Evangelho ${ }^{6}$, enquanto que o Compêndio, de forma precisa e breve, destaca que os filhos da Igreja, que ainda estão na terra como peregrinos, se reconhecem todos pecadores e sempre necessitados de conversão e purificação durante esta peregrinação ${ }^{7}$. Ao tratar sobre a necessidade que os batizados têm de conversão, acentua que o apelo à conversão feito pelo Senhor é contínuo e esse processo é um compromisso para toda a Igreja que, sendo santa, reúne pecadores em seu seio ${ }^{8}$. Não será isso um indicativo de que a Igreja precisa de conversão para viver de acordo com o Evangelho? E de uma conversão constante? Será que a teologia dogmática pode contribuir com algo, em especial no campo da eclesiologia?

É fato que o tema "conversão" é pouco presente nos materiais de eclesiologia; há referências gerais à conversão pessoal. Raramente defende-se a conversão como uma missão e identidade da Igreja e esse silêncio parece refletir a concepção que se tem da mesma. O Dizionario di Ecclesiologia, por exemplo, não contém os verbetes "conversão" e "metanoia". Porém, ao tratar do termo "riforma", acrescenta que João Paulo II refere-se ao número seis do decreto sobre o ecumenismo (Unitatis redintegratio) do Concílio Vaticano II com as palavras: "conversione, rinnovamento" e "«continua riforma»". O mesmo dicionário destaca que a Igreja precisa mais de penitência e conversão que de reforma, afirmando que essa penitência e essa conversão têm aplicação pessoal e comunitária ${ }^{9}$. Essa premissa de que os membros da Igreja vivem em um estado de conversão constante é presente na teologia e nos ensinamentos

${ }^{4}$ Cf. João Paulo II, Dives in misericordia, 13.

${ }^{5} \mathrm{Cf}$. Lumen gentium, 8, 12; Presbyterorum ordinis, 1, 12; Unitatis redintegratio, 4, 6.

${ }^{6}$ Catecismo, 821. Cf. Unitatis redintegratio, 7.

${ }^{7}$ Compêndio do Catecismo da Igreja Católica (São Paulo: Loyola, 2005), 165. Cf. Catecismo, 823-31, 868 .

${ }^{8}$ Compêndio do Catecismo da Igreja Católica, 299. Cf. Catecismo, 1427-9.

${ }^{9}$ Giovanni Tangorra, "Riforma”, in Dizionario di ecclesiologia, editor Gianfranco Calabrese, Philip Goyret, e Orazio F. Piazza, 1202-8 (Roma: Città Nuova, 2010), 1207-8. Cf. João Paulo II, Ut unum sint, 2, 4, 15-7, 35, 41, 82, 91. 
da Igreja, principalmente nos campos da teologia moral e da espiritualidade. Recentemente também associada a permanente conversão à Igreja, mas na dimensão pastoral: "conversão pastoral"10.

Este artigo tem por finalidade apresentar o princípio Ecclesia semper convertenda como eclesiológico, ou seja, também pertencente ao campo da teologia sistemática. Como fonte de pesquisa e inspiração para levantar essa hipótese foi escolhida a Exortação Apostólica Ecclesia in America de João Paulo II. Constatou-se que na literatura da área da dogmática não há produções científicas de outros autores sobre o problema apresentado. Foram escritos somente alguns artigos de cunho mais informal que representam mais uma reflexão sobre o estado da Igreja do que uma pesquisa a nível universitário. A referida encíclica, publicada em 1999, é sobre o encontro com Jesus Cristo vivo, caminho para a conversão, a comunhão e a solidariedade na América. Esse documento foi publicado na Acta Apostolicae Sedis ${ }^{11} \mathrm{em}$ espanhol. Além do documento final, também foram utilizados os materiais preparativos para o sínodo - Lineamenta ${ }^{12}$ e Instrumentum laboris ${ }^{13}$ - que apresentam a temática e o entorno do sínodo. Também foi usado o Elenchus unicus propositionum ${ }^{14}$, que considera os conteúdos mais importantes do sínodo, que serviram de base para a redação da exortação pós-sinodal. Destaca-se, a partir desses documentos, o que tem aplicação geral para toda a Igreja. Para alargar os horizontes de alguns termos, também são empregados outros documentos do mesmo papa e do Magistério que teriam influência na redação do documento e/ou confirmam a validade da temática em questão.

Para a realização deste tema decidiu-se pelo seguinte método de trabalho: Inicialmente convinha verificar as possíveis definições e formulações relacionadas à conversão e à continuidade da mesma segundo a fonte principal de

\footnotetext{
${ }^{10}$ Francisco, Evangelii gaudium, 25-33.

${ }^{11}$ Juan Pablo II, Exhortación Apostólica postsinodal Ecclesia in America sobre el encuentro con Jesucristo vivo, camino para la conversión, la comunión y la solidaridad en América (22 de enero del año 1999), $A A S$ 91, no. 8 (1999): 737-815 [a seguir, EAm].

${ }^{12}$ Sínodo de los Obispos, Asamblea Especial para America. Encuentro con Jesucristo vivo, camino para la conversión, la comunión y la solidaridad en América. „Lineamenta”, Ciudad del Vaticano 1996, accesso 17 Março 2020, http://www.vatican.va/roman_curia/synod/documents/ rc_synod_doc_01081996_usa-lineam_sp.html [a seguir, Lineamenta].

${ }^{13}$ Sínodo de los Obispos, Asamblea Especial para América. Encuentro con Jesucristo Vivo, camino para la conversión, la comunión y la solidaridad en América, „Instrumentum laboris”, Ciudad del Vaticano 1997, accesso 17 Março 2020, http://www.vatican.va/roman_curia/synod/ documents/rc_synod_doc_01091997_usa-instrlabor_sp.html [a seguir, Instrumentum laboris].

${ }^{14}$ Synodus Episcoporum. Coetus specialis pro America. Elenchus unicus propositionum, E Civitate Vaticana 1997, 1 [a seguir, Propositio, como na exortação].
} 
pesquisa, bem como seu surgimento na vida dos seguidores de Cristo. Depois, fez-se necessário identificar a dinâmica de realização dessa mesma conversão, considerando as circunstâncias que a rodeiam, com destaque para a missão da Igreja como continuadora da missão do Senhor. Por fim, aprofundada a relação existente entre a Igreja e seus membros, considerando a implicância destes na comunidade como um todo, sob o prisma da possibilidade de aplicar a recíproca construção de identidade entre o todo e suas partes ${ }^{15}$.

Este artigo será inicialmente discorrido sobre o encontro com Cristo, que conduz à conversão na Igreja. Depois transcorrido sobre os efeitos da conversão na vida da pessoa. Por fim, será aplicado à Igreja, no que se refere aos seus membros, a partir da conversão pessoal.

\section{O ENCONTRO COM CRISTO VIVO É CAMINHO PARA A CONVERSÃO NA IGREJA}

Jesus Cristo, durante seu ministério terreno, chamou à conversão por palavras e ações. E continua a agir por meio da Igreja, para que o ser humano também hoje se encontre com Ele e corresponda ao seu chamado. Esse tema é relembrado em Ecclesia in America, de João Paulo II, que afirma que o encontro com o Cristo vivo acontece igualmente no hoje da história e é fundamento e caminho para a conversão. Cristo vivo é o Senhor ressuscitado, considerado na totalidade de seu mistério que se faz encontrar principalmente em três lugares: na Sagrada Escritura, na liturgia e no ser humano, com destaque para os mais necessitados ${ }^{16}$. Assim, o encontro com o Senhor é a base daquilo que o papa chama de "programa de evangelização" para o agir da Igreja ${ }^{17}$. O encontro conduz à conversão e introduz o cristão na dinâmica de uma vida nova; a Igreja é instrumento e lugar de realização do apelo de Cristo (cf. Mc 1,15).

Toda a Sagrada Escritura, como relato da pedagogia de Deus na obra da redenção, revela a dinâmica de Deus encontrar-se com os homens (cf. Ex 33,7-11),

\footnotetext{
${ }^{15}$ A forma aplicada pode ser classificada como método teológico parcial, com acento na dimensão teológica descendente, ou humanização da Revelação. Esse aspecto da teologia descendente se relaciona ao mesmo tempo com uma compreensão dialógica e ascendente da Igreja. Tudo isso numa perspectiva escatológica. Cf. Celestyn S. Napiórkowski, Jak uprawiać teologię (Wrocław: Wydawnictwo Wrocławskiej Księgarni Archidiecezjalnej, 1991), 63-76.

${ }^{16}$ Propositio, 4: EAm 12.

${ }^{17} \mathrm{EAm}, 3$. Além da conversão, esse programa de evangelização proposto por Ecclesia in America também agrega a comunhão e a solidariedade.
} 
cujo coroamento se dá em seu filho Jesus; são os livros sagrados - lidos à luz da Tradição, dos Padres da Igreja e do Magistério e aprofundados pela oração - o primeiro lugar de encontro com Cristo presente em sua Igreja. Observamos a vocação dos primeiros discípulos, as conversões de Zaqueu, da Samaritana, de Maria Madalena, o encontro com os discípulos de Emaús, o acontecimento com o fariseu Saulo nos arredores de Damasco. João Paulo II, apoiado nas proposições dos bispos, salienta que esses encontros têm uma característica em comum: uma "força transformadora". Com isso, o encontro com Jesus é o início de um processo de autêntica conversão ${ }^{18}$. E isso se expressa, na vida dos que encontraram Jesus, ao tomarem iniciativa de sair de si - da tristeza, do isolamento, da busca de lucro a todo custo - inclusive transformando um grande e zeloso perseguidor em Paulo (pequeno), irmão daqueles que perseguia e anunciador do que tentava aniquilar (cf. At 9,3-30; 22,6-11; 26,12-18). Reconhecer Jesus que se revela no encontrar-se com ele é o primeiro passo para a responder à vontade de Deus (cf. Lc 24,13-35). No entanto, é preciso acolher a conversão proposta por Jesus e responder a ela sem reservas (o jovem rico não o fez de imediato, cf. Mc 10,17-22).

Ler e ouvir a palavra de Deus com a mesma atenção que os contemporâneos de Jesus de Nazaré produz frutos de conversão. E o lugar por excelência onde isso acontece é a liturgia, que, por sua vez, torna presente o mistério ${ }^{19}$. Cristo é presente nos sacramentos com seu poder eficaz, e na pessoa do sacerdote, que torna presente no sacrifício eucarístico a mesma e única oferta da cruz. O próprio Senhor fala na palavra proclamada, está no meio da comunidade reunida em seu nome (Mt 18,20) e o cume de sua presença real se dá nas espécies do pão e do vinho ${ }^{20}$. Sendo assim, Escritura e Eucaristia são, na liturgia, um acontecimento concreto que nos remete a Emaús e possibilita nosso encontro com o Ressuscitado ${ }^{21}$.

Além desses dois lugares onde Cristo está presente, o relato do juízo final (cf. Mt 25,31-46), apresenta mais um: "as pessoas, especialmente os pobres, com os quais Cristo se identifica" 22 . Ou seja, o próprio ser humano é lugar de encontro com Cristo. João Paulo II, no espírito da Gaudium et spes, destacou em sua encíclica programática - que Cristo se uniu com cada ser humano, e que o ser humano "é a primeira e fundamental via da Igreja". Essa união de

\footnotetext{
18 Propositio, 3: EAm 8.

${ }^{19}$ Propositio, 4: EAm 12.

${ }^{20}$ Sacrosanctum Concilium, 7: EAm 12.

${ }^{21}$ EAm 12.

22 Propositio, 4: EAm 12.
} 
Cristo com o homem existe até mesmo quando este não tem consciência disso $^{23}$ : "toda vez que fizestes isso a um desses meus irmãos menores, a mim o fizestes" (Mt 25,40b).

Os encontros com Jesus, além de servirem para despertar para a conversão e a fé (cf. Mc 1,15), fortalecem a fé dos crentes, favorecendo o amadurecimento de uma fé convicta, viva e atuante. O fato de Jesus ensinar seus apóstolos em particular também aponta para a missão de agirem em conjunto. São eles que conduzem outras pessoas ao encontro com o Senhor, por isso, a Igreja é hoje instrumento real de encontro com Jesus Cristo, um encontro vivo e sem abstração ${ }^{24}$. E as tarefas confiadas a pessoas concretas não são isoladas da realidade comunitária, pois o que toca a realidade de um membro reflete no corpo todo (1 Cor 12,12-13). O mesmo se refere à conversão, que é, antes de mais nada, pessoal, mas que tem efeitos igualmente na sociedade ${ }^{25}$.

Jesus encontrou-se com pessoas em diferentes situações existenciais, seja claramente em pecado ou em sincera busca de Deus, com destaque para Maria de Nazaré, que foi agraciada pelo Altíssimo de forma especial. O contexto existencial é importante, pois tanto o pecado quanto a virtude existem atrelados a determinada realidade, como consequência de atos pessoais ${ }^{26}$. Isso vale para a atualidade, assim como para o tempo de Jesus, e é na realidade concreta de cada um que acontece o encontro com Jesus ${ }^{27}$. A vida dos santos ${ }^{28}$ e a piedade popular ${ }^{29}$ em suas diversas formas podem ser maneiras de despertar o desejo de buscar o encontro e uma união cada vez mais profunda com o Senhor, considerando que o engajamento nesta busca e aprofundamento da conversão e intimidade com Deus dependem da resposta pessoal por uma espiritualidade autêntica e fiel à Igreja. Pois o encontro real com Deus conduz a uma constante mudança de vida, segundo o plano de Deus, e a Igreja tem a missão de promover e custodiar isso.

A mudança de vida é um critério comum nos encontros com o Senhor e apresenta a abertura à ação de Deus, a partir da qualitativa transformação para a qual cada pessoa é convidada: seja um chamado a sair de imediato de

\footnotetext{
${ }^{23}$ Redemptor hominis, 13-14, cf. Gaudium et spes, 91.

${ }^{24}$ Propositio, 4: EAm 12.

${ }^{25}$ Lineamenta, 22.

${ }^{26}$ Reconciliatio et paenitentia, 16; EAm 13.

${ }^{27}$ EAm 13.

${ }^{28} \mathrm{EAm} 15$

${ }^{29} \mathrm{EAm} 16$.
} 
situações de miséria humana a começar pelo perdão de Deus e conversão ${ }^{30}$, seja também a constante busca de fazer a vontade de Deus ${ }^{31}$. A mudança de vida autentica o encontro e a resposta pessoal em cooperar com a força transformadora que provém de Cristo. $\mathrm{O}$ sair de uma realidade totalmente negativa implica começar a trilhar os caminhos do Senhor, passando por um processo de constante transformação, ou seja, de conversão, estabelecendo constante amizade com Cristo e desejo de imitá-lo. Esse processo positivo é comum a ambos - aos que já buscavam agradar a Deus e aos que estavam em situação de pecado - e é marcado pelo aprofundar da amizade com Jesus numa permanente mudança de vida, conversão, no desejo de imitar cada vez mais o Senhor ${ }^{32}$.

O encontro com o Senhor é a porta para a conversão. A constância e o renovamento desse encontro são via para a contínua conversão ${ }^{33}$. A oração, em suas formas litúrgica e pessoal ${ }^{34}$, e os sacramentos - principalmente a Eucaristia são lugares privilegiados de encontro com Cristo vivo ${ }^{35}$. Os encontros com Jesus frutificam em profunda transformação naquele que não se fecha a Ele. Transformado, anuncia o que experienciou, dando testemunho do encontro. E isso não será necessariamente um ensinar os outros, mas sim um servir de instrumento para que também outros se encontrem pessoalmente com Cristo (assim o fez a samaritana - Jo 4,29) ${ }^{36}$, para que também eles vivam uma experiência religiosa de primeiro grau ${ }^{37}$. É o encontro com Deus Filho que desperta e conduz à conversão e à fé em suas particularidades ${ }^{38}$. Encontro esse que não é superficial nem de momento, passageiro, mas profundo e pessoal, tornando-se com isso decisivo, como aconteceu com Zaqueu e Saulo / Paulo, por exemplo.

${ }^{30}$ Sobre isso, mais em Reconciliatio et paenitentia, 13-14, onde João Paulo II desenvolve sobre o mistério do pecado diante do amor de Deus, que é maior que o pecado.

${ }^{31}$ EAm 13.

32 EAm 13.

${ }^{33}$ Propositio, 26: EAm 28.

${ }^{34}$ Propositio, 27: EAm 29.

${ }^{35}$ EAm 35.

${ }^{36}$ EAm 68.

${ }^{37}$ Cf. Sabino S. Acquaviva, L'eclissi Del sacro nella civilità industriale, $5^{\text {a }}$ ed. (Milano: Comunità, 1981), 79-80; Stefano Martelli, "A experiência religiosa. A religião do ponto de vista do mundo vital, parte II", Ciberteologia - Revista de Teologia \& Cultura" 2, no.7 (2006): 22.

${ }^{38} \mathrm{EAm} 12$. 


\section{CONVERSÃO - CHAMADO À NOVA VIDA PELA CONTÍNUA TRANSFORMAÇÃO PESSOAL EM CRISTO}

Em Ecclesia in America conversão é o eixo para a realização dos outros dois objetivos do documento: a comunhão e a solidariedade ${ }^{39}$. Despertada pelo encontro com Cristo, conduz ao aprofundamento desta proximidade com Ele, que se manifesta na integridade da vida do crente. No citado documento, a comunhão com Cristo e com os irmãos e o servir aos outros pela solidariedade são frutos da conversão ${ }^{40}$.

No Novo Testamento, conversão é, em geral, tradução da palavra metanoia, que significa mudança de mentalidade. Conversão, na definição de Ecclesia in America, tem, entre outros significados, o sentido de "mudança de mentalidade (metanoia) [que] consiste no esforço de assimilar os valores evangélicos, que contrastam com as tendências dominantes no mundo"41. Mas não é caracterizada somente por outra forma de pensar em nível intelectual, e sim por uma reavaliação das próprias convicções e maneira de agir à luz dos critérios evangélicos ${ }^{42}$, bem como uma transformação interior ${ }^{43}$. Dentro do Magistério, será identificada pelo adequar-se aos valores evangélicos e pelo aproximar-se de Jesus Cristo, tendo por auxílio a teologia e a moral ${ }^{44}$. Converter-se ao Evangelho implica examinar tudo o que circunda a pessoa em cada dimensão da própria vida sob o prisma da Boa Nova de Cristo ${ }^{45}$.

O chamado de Jesus, "Convertei-vos e crede no Evangelho" (Mc 1,15), é continuamente atual e apresenta que a conversão é condição para acreditar na Boa Nova com uma fé efetivada no amor (cf. Gl 5,6). Essa conversão se refere à nova forma de viver a própria vida e a Palavra e os sacramentos. Especialmente a reconciliação e a Eucaristia eficazmente acompanham este dinamismo ${ }^{46}$, sendo fonte de graças para agir segundo o Reino. Esse novo estilo de vida une a fé professada aos atos do cotidiano. Atos estes que autenticam o processo de conversão ${ }^{47}$.

\footnotetext{
${ }^{39}$ Cf. Lineamenta, 66.

${ }^{40}$ EAm 52.

${ }^{41}$ EAm 28.

${ }^{42}$ EAm 26.

${ }^{43}$ Cf. Reconciliatio et paenitentia, 4.

${ }^{44}$ EAm 53.

${ }^{45}$ EAm 28.

${ }^{46}$ EAm 26.

${ }^{47}$ EAm 26.
} 
A meta da conversão é a santidade ${ }^{48}$. Assim, a vida do cristão será "em Cristo" e "no Espírito", acolhida na fé, expressa no amor e traduzida em vida pela esperança no cotidiano da comunidade ${ }^{49}$, formando seu gênero de espiritualidade, isto é, sendo uma vida guiada pelo Espírito Santo em sua integridade $^{50}$. A conversão é uma resposta pessoal à vontade do Pai. Por mais que a Igreja como comunidade participe desse processo, a mudança é, inicialmente, pessoal. O desenvolvimento é individual e ao mesmo tempo ocorre na comunidade de fé, com ajuda da mesma e para edificação de ambos. Outra característica que se realiza numa pessoa concreta é a continuidade, independente de idade, maturidade; assemelhar-se a Cristo é tarefa para a vida toda até à plenitude da vocação cristã, a santidade, e só a morte encerra. É na consciência humana que cada indivíduo conduz o diálogo decisivo e absolutamente pessoal entre a graça e a própria liberdade, vividos em uma concreta situação existencial ${ }^{51}$.

Acolher o chamado à conversão e à fé que Jesus faz (cf. Mc 1,15) significa almejar aos desejos de Cristo, e a fé pessoal e consciente conduz a pessoa ao sentido da própria vida, em processo de contínua conversão pessoal ${ }^{52}$. A unidade entre a fé e a vida (viver aquilo que se professa) é condição para considerar seriamente a conversão ${ }^{53}$, e essa adequação cada um a faz por si. Isso não significa que essa busca da vontade de Deus seja algo individualista, por mais individual que seja. A Igreja tem a missão de acompanhar e oferecer instrumentos necessários, como os sacramentos e direção espiritual à luz da fé $^{54}$. Além disso, os sacramentos e a oração nos colocam em união com Cristo e, por ele, em comunhão com todos os cristãos ${ }^{55}$. O próprio Deus é comunhão, e chama a todos para a comunhão trinitária, por meio do Espírito Santo que incessantemente age ${ }^{56}$. Unindo as pessoas, une a Igreja.

$\mathrm{Na}$ Igreja as pessoas podem, pelo encontro com Cristo, descobrir o amor do Pai (cf. Jo 14,9). O Senhor continua a agir por meio do "Paráclito (cf. Jo 16,7), que transforma os fiéis, dando-lhes a nova vida" ${ }^{57}$. É essa força do Espírito

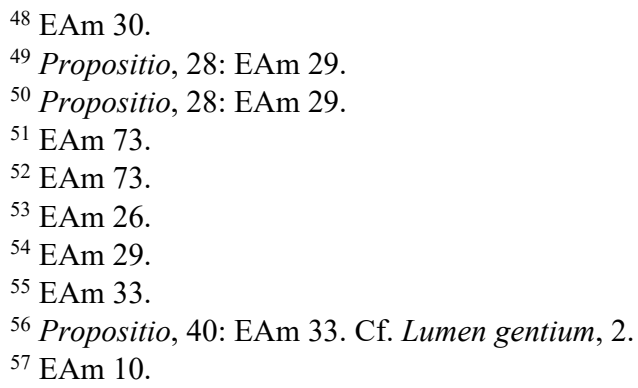


que dá ao ser humano a capacidade de amar a exemplo do amor divino. A graça divina o capacita a transformar o mundo ${ }^{58}$, pois, a partir da conversão, muda a vida daquele que se encontrou com Jesus ${ }^{59}$. Essa força ou graça provém do Espírito e da Palavra, manifesta-se e age de forma especial por meio dos sacramentos ${ }^{60}$ e garante a eficácia do Evangelho; a conversão constante é um processo de autêntica identificação com o estilo pessoal de Jesus $^{61}$. Responder e corresponder a essa graça, no entanto, depende de uma adesão pessoal, pois a própria evangelização respeita o santuário da consciência de cada pessoa. É nela que se passa o diálogo decisivo e totalmente pessoal entre a graça e a liberdade do ser humano ${ }^{62}$.

Seguir Jesus Cristo é imitá-lo durante toda a vida. Enquanto isso dura, também persiste a transformação do coração ${ }^{63}$. Nisso se verifica o postulado: o caminho do seguimento de Jesus é um caminho de contínua conversão. É contínuo porque a decisão da conversão constantemente é enfraquecida pelas tentações, entre elas as correntes e tendências mundanas. Enquanto isso permanece, também perdura o engajamento em se aproximar de Cristo e não deixar-se vencer pela concupiscência. Sendo assim, a conversão se expressa num estado de contínua vigilância e prontidão como desejosa espera por participar na comunhão trinitária. O Pai nos criou e quer-nos santos e perfeitos (cf. Mt 5,48; Lv 19,2;11,44; 1 Pd 1,16). O Espírito Santo age intermitentemente facilitando para que todos possam corresponder e participar nesta comunhão, da qual a Igreja é sinal e na qual o ser humano é chamado à união com a comunidade ${ }^{64}$. Assim, o chamado para estar com o Senhor (cf. Jo 1,38-39), que é para toda a vida ${ }^{65}$, é reafirmado pelo esforço do Divino Espírito em aperfeiçoar a comunhão entres os humanos e Deus. Como o empenho divino é ininterrupto, da mesma forma é a correspondente resposta humana, que se concretiza na conversão - e na fé - pessoal: permanente e na vida toda. Nesta caminhada para a conversão constante, João Paulo II e os padres sinodais destacam que é fundamental renovar com igual constância o encontro com Jesus Cristo vivo, ponto de partida para a conversão ${ }^{66}$.

\footnotetext{
${ }^{58} \mathrm{EAm} 10$.

${ }^{59}$ EAm 8.

${ }^{60}$ EAm 12.

${ }^{61}$ Propositio, 26: EAm 28.

${ }^{62}$ EAm 67, 68, 73.

${ }^{63}$ Cf. Lineamenta, 16.

${ }^{64}$ Propositio, 40: EAm 33. Cf. Lumen gentium, 2.

${ }^{65}$ EAm 68

${ }^{66}$ Por. EAm 28.
} 


\section{IGREJA EM CONTÍNUA CONVERSÃO - TRANSFORMAÇÃO DA IGREJA EM CRISTO A PARTIR DE SEUS MEMBROS}

A dinâmica da conversão pessoal é um acontecimento que diz respeito a toda a Igreja, que recebeu de Jesus a missão de continuar a presença dele na terra. Por isso, como comunidade oferece meios de salvação para os homens, sendo presença viva e Corpo de Cristo por meio do Espírito ${ }^{67}$. Na Igreja o ser humano se encontra com Cristo e acolhe sua mensagem, se converte e vive na promessa da vida eterna. Essa dinâmica de encontro e conversão, que em primeiro plano é pessoal, é também pertencente a toda a comunidade eclesial, que se assemelha a seu Fundador e Senhor.

A Igreja, portadora e anunciadora dos ensinamentos de Cristo, auxilia o homem a encontrar-se com o Senhor e, por meio da proximidade pessoal, se enriquece também, pois quanto mais unidos à Cabeça estão os membros, melhor está o Corpo, que melhor desempenha sua missão de ser instrumento de salvação ${ }^{68}$. A Igreja como comunidade (communio) não exclui a individualidade e diversidade de participação de seus membros bem como não limita a esfera da liberdade humana. Ela é instrumento da graça e tem como missão garantir aos homens acesso à mesma, considerando que a responsabilidade moral é pessoal. Nesse contexto, a diversidade de membros compõe a Igreja, Corpo de Cristo-Cabeça, e o agir de um membro reflete no agir da comunidade. Essa unidade dos membros dá à Igreja determinada identidade; isso também no que diz respeito ao vivenciar o encontro com Cristo, a conversão e a fé no Evangelho em vista da vocação à santidade e união com Deus. Esta comunidade eclesial diferencia-se das demais sociedades humanas, pois é Deus quem a conserva em comunhão.

A Igreja tem a missão de conduzir seus membros à salvação. De natureza, é corpo de Cristo e não necessita de purificação, mas enquanto a salvação dos membros não acontece, em certa medida, acaba compartilhando da sorte destes, ocupando-se de cada um e oferecendo meios para que alcancem o fim último da própria vida. Cristo, não sendo pecador (cf. 2 Cor 5,21), assumiu a condição humana para expiar os pecados do povo (cf. Hb 2,17). A Igreja, a exemplo de Cristo-Cabeça, tem aos seus cuidados pecadores, sem deixar de ser santa. Por isso, constantemente necessita de purificação, penitência e renovação e realiza isso com a força do Senhor ressuscitado até revelar por completo

\footnotetext{
${ }^{67}$ EAm 7, 12, 39.

${ }^{68}$ EAm 26, 33, 34, 39, 68.
} 
o Seu mistério ${ }^{69}$. Isso não significa que a Igreja, ao dividir a sorte dos membros peregrinos, seja sujeita à condenação, mas indica que ela própria é peregrina e o que acontece com os membros é acontecimento interno da Igreja, pois se um membro sofre, todos os membros sofrem com ele (cf. 1 Cor 12,26).

Cada pessoa, sem exceção, ocupa lugar central no Evangelho de Jesus (cf. Lc 12,22-29) ${ }^{70}$, pois Ele quer devolver ao ser humano a semelhança divina (cf. Gn 1,26; Mt 5,48). Assim como o ser humano ocupa lugar central na mensagem do Senhor, assim também Cristo é o ponto central do anúncio da conversão $^{71}$ realizado pela Igreja. Nesse contexto, a Igreja toda, santa por Cristo, ruma à salvação dada por Deus tendo em seu seio pecadores, necessitados de conversão $^{72}$. Por isso a necessidade da Igreja de viver a proximidade com Cristo vivo e converter-se. Esse estar próximo do Senhor não tem por objetivo analisar a pessoa de Cristo, mas sim iniciar um encontro duradouro com Ele ${ }^{73}$. É este encontro fonte da graça transformadora e de renovação dos vínculos na comunidade.

É pelo encontrar-se com Jesus e pela conversão que o ser humano e a Igreja assemelham-se a Deus (cf. Mt 5,48). Pois a própria Igreja renova-se a partir da vivência de cada um de seus membros ${ }^{74}$ na medida em que o ser humano, encontrando-se com o Cristo, renova-se e, renovando-se, renova a Igreja. Isso será consequência da experiência com Jesus Cristo na totalidade do mistério, consciente do chamado contido no próprio batismo: imitar o Senhor, estabelecer comunhão e assumir a missão de levar Cristo ao mundo ${ }^{75}$. Nesse plano, as relações humanas assumem papel importante, visto ser a parte visível do mistério.

As relações humanas na Igreja têm seu lugar, que não é preponderante, mas também não é desnecessário. São elas estabelecidas no nível ainda muitas vezes marcado pela mancha do pecado e precisam de direcionamento para serem virtuosas e é exatamente a humanidade que evidencia a realidade do Reino. Daí que a renovação destes vínculos por meio do processo de conversão permitirá o direcionamento dos mesmos a Deus. Isso porque, na Igreja, a comunhão com os outros não é o objetivo em si mesmo, mas é consequência da comunhão

\footnotetext{
${ }^{69}$ Lumen gentium, 8 .

${ }^{70} \mathrm{EAm} 57$

${ }^{71}$ EAm 3.

${ }^{72} \mathrm{Cf}$. Lumen gentium, 8.

${ }^{73}$ Lineamenta, 6.

${ }^{74}$ EAm 7. Cf. EAm 1.

${ }^{75}$ Propositio, 54: EAm 44.
} 
com o Pai, por Cristo, no Espírito Santo. A busca pessoal da santidade, rejeitando a mentalidade do mundo pela conversão, se torna renovação da Igreja. Esta renovação, por sua vez, é resultado da vida de seus membros segundo o Evangelho ${ }^{76}$. A renovação da Igreja faz com que nela se torne mais visível o Cristo. Pois é desejo do próprio Cristo-Cabeça que não haja no seu Corpo divórcio entre a fé e a vida e, consequentemente, entre a vocação e a santidade, na busca por uma forma de vida mais real em fraternidade e santidade. Vale ressaltar que o caminho para isso é o da conversão e tem seu início no encontro com o Messias ${ }^{77}$.

A pessoa, ao conservar a intimidade com o Senhor, experiencia a graça e se dispõe constantemente a assumir o estilo pessoal Dele. Daí que as faltas de ordem pessoal e nas relações com os demais demonstram a necessidade de contínua conversão. Converter-se ao Evangelho significa assumir o compromisso de organizar toda a vida segundo ele. O mesmo significa para a Igreja: não viver como Jesus significa estar necessitada de conversão à Boa Nova. Por não ser livre de acidentes dissonantes com a sua natureza de Corpo Místico de Cristo, a Igreja precisa de purificação dessas incoerências. Pois as faltas no viver o Evangelho do Senhor acabam por refletir na pouca eficiência do anúncio, visto este não repercutir na vida do mensageiro e da Igreja ${ }^{78}$. Isso não significa que o Filho de Deus deixou a sua Igreja, mas que os membros dela não estão totalmente voltados para Ele. Sobre isso João Paulo II desenvolveu em outro documento, destacando que anunciar a conversão é missão fundamental e primeira da Igreja ${ }^{79}$ e que só é adequado anunciar a conversão estando em processo de diária conversão pessoal ${ }^{80}$.

Ora, o pecado é sempre um ato pessoal que reflete na relação com os outros - por mais que algumas vezes seja conceituado também como social ${ }^{81}$. Ele se encontra em estruturas onde os humanos se fazem presentes. Por isso, a Igreja, no plano humano, precisa daquilo que o Concílio chamou de constante reforma ${ }^{82}$. Encontra-se nessa constatação um relembrar da missão de anunciar a conversão e no que ela consiste ${ }^{83}$. Somente a Igreja reconciliada poderá conciliar os povos e, para isso, precisa se tornar cada vez mais comunidade de

\footnotetext{
${ }^{76}$ Cf. EAm 32.

${ }^{77}$ Propositio, 25.

${ }^{78}$ Propositio, 34: EAm 27.

${ }^{79}$ Redemptoris missio, 20.

${ }^{80}$ Redemptoris missio, 47.

${ }^{81}$ EAm 13. Cf. Reconciliatio et paenitentia, 16.

${ }^{82}$ Lineamenta, 26; Unitatis redintegratio, 6.

${ }^{83}$ EAm 53.
} 
discípulos de Cristo unidos pelo mandato da constante conversão ao Senhor e da vida digna de pessoas novas em espírito e na prática da reconciliação ${ }^{84}$. A conversão é reconciliação com Deus, consigo mesmo e com os outros por meio da radical superação do pecado que estabelece distância entre o sujeito e Cristo. Considerando que cada pecado pessoal tem consequências na sociedade, também a conversão pessoal terá implicâncias sociais ${ }^{85}$. Conversão é um chamado direcionado não somente para pessoas isoladas, mas também para agrupamentos, instituições, estruturas sociais conduzidos por pessoas dotadas de liberdade e responsabilidade ${ }^{86}$.

Esse aspecto da conversão da Igreja não questiona a instituição divina da mesma, que é conservada pelo Espírito Santo no anúncio da Revelação, mas, por sua vez, refere-se à comunidade de pessoas, que precisam de constante conversão. Conversão esta que se aplica aos membros a às estruturas pastorais por eles conduzidas, para que o testemunho da proximidade do Reino seja autêntico ${ }^{87}$. A Igreja como sinal de comunhão é expressão da participação dos seus membros na vida de Cristo $^{88}$. Qualquer falta nessa identificação com o Senhor, na reconciliação e no conduzir estes membros até a Cabeça que é Cristo evidencia a necessidade da renovação e da conversão. Renovação, no vocabulário de Paulo de Tarso, significa revestir-se do novo homem que "vai sendo sempre renovado à imagem do seu criador" $(\mathrm{Cl} 3,10)^{89}$. Por isso a vocação universal à conversão é para a Igreja esperança de renovação da própria fé $^{90}$. Este é o melhor caminho para a Verdade que é Cristo. Visto que fé renovada significa fé consciente e pessoal ${ }^{91}$, então a Igreja vive essa fé na medida que os fiéis assim vivem e a eclesiologia de comunhão concebe essa realidade em estreita unidade com todo o mistério da Igreja que tem procedência divina ${ }^{92}$.

Ora, a unidade da Igreja como Povo de Deus revela o fato de que imitação de Cristo, mútua comunhão e missão pertencem à dignidade de todos os batizados. Daí convém que o engajamento dos mesmos destaque, ainda mais,

\footnotetext{
${ }^{84}$ Reconciliatio et paenitentia, 9.

${ }^{85}$ Lineamenta, 22.

${ }^{86}$ Lineamenta, 16.

${ }^{87}$ Instrumentum laboris, 24. Cf. Evangelii nuntiandi, 15.

${ }^{88}$ EAm 33.

${ }^{89} \mathrm{EAm} 32$.

${ }^{90}$ EAm 28.

${ }^{91}$ EAm 73.

${ }^{92} \mathrm{Cf}$. Instrumentum laboris, 33.
} 
por meio dos membros, as características divinas da Igreja ${ }^{93}$ que, por sua vez, permaneceria somente sociedade humana ao não corresponder ao chamado do seguimento do Senhor pela conversão e fé (cf. Mc 1,15). Esse povo, reunido na união da Trindade e vivendo em espírito de comunhão, conduz ao encontro com Cristo vivo também aqueles que ainda não fazem parte do número dos batizados, cumprindo assim o último envio do Ressuscitado (cf. Mc 16,15). À unidade do povo segue-se a unidade interior e integral entre fé e obras, que é essencial para responder autêntica e cotidianamente ao chamado da vocação universal à santidade ${ }^{94}$. E a conversão, como parte integrante do peregrinar até Deus, consiste, para a Igreja e seus membros, no processo que conduz até a santidade. Essa conversão é então caminho para a santidade, cujo exemplo a ser seguido por cada um e por toda a Igreja é Jesus Cristo, o Santo de Deus (cf. Mc 1,24), que nos deixou o testamento do amor até a entrega da própria vida (cf. Jo 15,12-13). Resulta disso que a imitação da santidade divina significa prolongar o Seu amor na história ${ }^{95}$.

A busca da renovação e da santidade num processo de contínua conversão tem por objetivo permitir que o sinal de Cristo brilhe mais claramente na face da Igreja ${ }^{96}$. Essa é a finalidade que a Igreja quer alcançar para cada um de seus membros e, consequentemente, para si. A unidade dos membros da Igreja faz de todos colaboradores da graça de Deus. A busca da perfeição por meio da conversão enriquece os membros e o corpo, potencializando o testemunho de Jesus Cristo vivo, que se torna mais visível em seus membros e na comunidade como um todo.

\section{CONCLUSÃO}

O objetivo deste artigo foi verificar se o postulado Ecclesia semper convertenda consiste em princípio eclesiológico. Como fonte principal de pesquisa empregada a exortação apostólica Ecclesia in America de João Paulo II. Analisando também outros documentos da Igreja, pôde-se perceber que esse postulado pode ser identificado igualmente numa abordagem mais ampla dos textos do Magistério. Sendo assim, é possível formular as seguintes conclusões:

\footnotetext{
${ }^{93}$ Propositio, 54: EAm 44.

${ }^{94}$ EAm 26.

${ }^{95}$ Propositio 29: EAm 30.

${ }^{96}$ Lumen gentium, 15.
} 
- A partir do documento abordado, positivamente verificada a hipótese Ecclesia semper convertenda como princípio eclesiológico. Constata-se, além disso, que a conversão tem como fonte o próprio mistério Divino revelado em Jesus Cristo, que chama à conversão e à fé no Evangelho. Cumprimento da conversão será a comunhão com Deus e com as pessoas na Igreja;

- Ecclesia semper convertenda é um princípio claramente baseado na Revelação, com embasamento bíblico e fundamentado na Trindade que inicia a obra e acompanha os seres humanos com Sua graça por meio da Igreja, desejando que se encontrem na comunhão com Deus. Na realização desse princípio cada Pessoa Divina participa;

- A conversão constante da Igreja em seus membros não nega a santidade da mesma enquanto destaca que cada um e a comunidade como um todo está em peregrina aproximação de Deus, para crescer em graça e santidade. Além do mais, confirma a primazia de Deus em chamar, não permitindo que a busca pela santidade seja algo puramente humano. Esse princípio também reafirma a esperança escatológica dos chamados e contribui para o diálogo ecumênico;

- Finalmente, considera-se que esse tema tem ampla abrangência e é profundamente ligado à fé católica. Visto a dimensão personalista deste princípio, o termo "conversão" apresenta-se como mais adequado que "reforma", "renovação" e "reconstrução", frequentemente utilizados até então.

\section{BIBLIOGRAFIA}

A Bíblia, Novo Testamento. São Paulo: Paulinas, 2015.

Acquaviva, Sabino S. L'eclissi del sacro nella civilità industriale. $5^{\mathrm{a}}$ ed. Milano: Edizioni di Comunità, 1981.

Catecismo da Igreja Católica. Edição Típica Vaticana. São Paulo: Loyola, 2000.

Compêndio do Catecismo da Igreja Católica. São Paulo: Loyola, 2005.

Francisco. Exortação Apostólica Evangelii gaudium. 2a ed. São Paulo: Loyola, 2014.

Hable, Edson J. "Ecclesia semper convertenda" jako zasada eklezjologiczna wedtug adhortacji Jana Pawta II "Ecclesia in America". Monografia (Magistratura em Teologia Dogmática), Departamento de Teologia, Universidade Católica de Lublin João Paulo II, Lublin 2020.

Jan Paweł II. "Adhortacja apostolska Reconciliatio et paenitentia o pojednaniu i pokucie w dzisiejszym posłannictwie Kościoła”. In Jan Paweł II. Adhortacje apostolskie Ojca Świętego Jana Pawła II, 249-347. Kraków: Znak, 1996.

Jan Paweł II. "Encyklika Dives in misericordia o Bożym miłosierdziu (30 listopada 1980 r.)". In Jan Paweł II. Encykliki Ojca Świętego Jana Pawła II, 77-139. Kraków: Znak, 1996.

Jan Paweł II. "Encyklika Redemptor hominis u początku swej papieskiej posługi (4 marca 1979 r.)". In Jan Paweł II. Encykliki Ojca Świętego Jana Pawła II, 5-76. Kraków: Znak, 1996. 
Juan Pablo II. "Exhortación apostólica postsinodal Ecclesia in America sobre el encuentro con Jesucristo vivo, camino para la conversión, la comunión y la solidaridad en América (22 de enero del año 1999)". AAS 91, no. 8 (1999): 737-815.

Martelli, Stefano. "A experiência religiosa. A religião do ponto de vista do mundo vital, parte II". Ciberteologia - Revista de Teologia \& Cultura 2, no. 7 (2006): 21-39.

Napiórkowski, Stanisław C. Jak uprawiać teologię. Wrocław: Wydawnictwo Wrocławskiej Księgarni Archidiecezjalnej, 1991.

Paulus VI. "Adhortatio apostolica Evangelii nuntiandi de Evangelizatione in mundo huius tempore (8 Decembris 1975)". AAS 68, no. 1 (1976): 5-76.

Sínodo de los Obispos. Asamblea Especial para América. Encuentro con Jesucristo vivo, camino para la conversión, la comunión y la solidaridad en América. „Lineamenta”. Ciudad del Vaticano 1996. Accesso 17 Março 2020. http://www.vatican.va/roman_curia/synod/documents/ rc_synod_doc_01081996_usa-lineam_sp.html.

Sínodo de los Obispos. Asamblea Especial para América. Encuentro con Jesucristo Vivo, camino para la conversión, la comunión y la solidaridad en América. „Instrumentum laboris”. Ciudad del Vaticano 1997. Accesso 17 Março 2020. http://www.vatican.va/roman_curia/synod/ documents/rc_synod_doc_01091997_usa-instrlabor_sp.html.

Sobór Watykański II. „Dekret o działalności misyjnej Kościoła Ad gentes divinitus”. In Sobór Watykański II. Konstytucje, dekrety, deklaracje. Tekst łacińsko-polski, 674-743. Poznań: Pallottinum, 2008

Sobór Watykański II. „Dekret o ekumenizmie Unitatis redintegratio”. In Sobór Watykański II. Konstytucje, dekrety, deklaracje. Tekst tacińsko-polski, 302-33. Poznań: Pallottinum, 2008.

Sobór Watykański II. „Dekret o posłudze i życiu prezbiterów Presbyterorum ordinis”. In Sobór Watykański II. Konstytucje, dekrety, deklaracje. Tekst tacińsko-polski, 750-805. Poznań: Pallottinum, 2008

Sobór Watykański II. „Konstytucja dogmatyczna o Kościele Lumen gentium”. In Sobór Watykański II. Konstytucje, dekrety, deklaracje. Tekst łacińsko-polski, 144-255. Poznań: Pallottinum, 2008.

Sobór Watykański II. „Konstytucja duszpasterska o Kościele Gaudium et spes”. In Sobór Watykański II. Konstytucje, dekrety, deklaracje. Tekst tacińsko-polski, 824-981. Poznań: Pallottinum, 2008.

Sobór Watykański II. „Konstytucja o liturgii świętej Sacrosanctum Concilium”. In Sobór Watykański II. Konstytucje, dekrety, deklaracje. Tekst tacińsko-polski, 48-107. Poznań: Pallottinum, 2008.

Synodus Episcoporum. Coetus specialis pro America. Elenchus unicus propositionum. E Civitate Vaticana, 1997

Tangorra, Giovanni. "Riforma". In Dizionario di ecclesiologia, editor Gianfranco Calabrese, Philip Goyret, e Orazio F. Piazza, 1202-8. Roma: Città Nuova, 2010. 


\section{ECCLESIA SEMPER CONVERTENDA COMO PRINCÍPIO ECLESIOLÓGICO SEGUNDO A EXORTAÇÃO ECCLESIA IN AMERICA DE JOÃO PAULO II}

\section{R e s u mo}

O objetivo deste artigo é a verificação da hipótese se Ecclesia semper convertenda é um princípio eclesiológico. O estudo baseia-se na exortação pós-sinodal Ecclesia in America de João Paulo II. A hipótese foi verificada positivamente como princípio eclesiológico. Ecclesia semper convertenda abrange: a) o mistério de Deus como fonte de conversão; b) a Revelação em Jesus Cristo que revela ao ser humano o plano divino do Reino de Deus pelo chamado à conversão e a fé no Evangelho; c) a comunhão com Deus e com as pessoas na Igreja como cumprimento da conversão; d) a realização da missão da Igreja como resultado da conversão pessoal e comunitária. Conversão / metanoia tem fundamentação profundamente teológica; provém da Sagrada Escritura e se dirige à vida toda daquele que acolhe o chamado de Jesus Cristo e corresponde integralmente. $\mathrm{O}$ tema tem amplo alcance e aplicações e é relacionado à fé cristã, sendo hermenêutica do Evangelho e da Igreja.

Palavras-chaves: conversão; metanoia; Igreja; João Paulo II; Ecclesia in America.

\section{ECCLESIA SEMPER CONVERTENDA JAKO ZASADA EKLEZJOLOGICZNA WEDŁUG ADHORTACJI JANA PAWŁA II ECCLESIA IN AMERICA}

\section{Streszczenie}

Celem pracy była weryfikacja hipotezy, zgodnie z którą dewiza Ecclesia semper convertenda stanowi zasadę eklezjologiczną. Studium opiera się na posynodalnej adhortacji Ecclesia in America Jana Pawła II. Hipoteza odnosząca się do tej dewizy została pozytywnie zweryfikowana na podstawie adhortacji Ecclesia in America - jako zasadzie eklezjologicznej. Obejmuje ona: a) misterium Boga jako źródło nawrócenia; b) Objawienie w Jezusie Chrystusie - ukazującym człowiekowi Boży zamiar królestwa Bożego przez nawrócenie i wiarę w Ewangelię; c) komunię z Bogiem i z ludźmi w Kościele jako wypełnienie nawrócenia; d) misję Kościoła jako owoc nawrócenia, które ma implikacje nie tylko dla pojedynczego człowieka, lecz także dla wspólnoty Kościoła. Nawrócenie / metanoia ma uzasadnienie głęboko teologiczne; pochodzi z Pisma Świętego i odnosi się do całego życia osoby wierzącej, która odpowiada na wezwanie Jezusa Chrystusa, angażując się myśleniem i działaniem. Temat ma szeroki zakres i zastosowanie i jest głęboko związany z wiarą katolicką - stanowi hermeneutykę Ewangelii i Kościoła.

Słowa kluczowe: nawrócenie; metanoia; Kościół; Jan Paweł II; Ecclesia in America. 